Brit. Heart J., 1964, 26, 528.

\title{
GUANETHIDINE AND METHYLDOPA: A HÆMODYNAMIC STUDY
}

\author{
BY \\ D. A. CHAMBERLAIN AND JANE HOWARD \\ From the Department of Cardiology, St. Bartholomew's Hospital, London E.C.1
}

Received January 20, 1964

Guanethidine and methyldopa are commonly used drugs in the treatment of hypertension, but the manner in which they act on the circulation to lower the blood pressure remains controversial. Systemic arterial pressure depends on both cardiac output and total peripheral resistance, and a reduction in either of these can result in a fall of pressure. Guanethidine has been said by some to act principally by lowering peripheral resistance (Lichtlen, Schaub, and Bühlmann, 1960; Roy, Mathur, and Bhatia, 1961; Taylor et al., 1962), while others have considered a fall in cardiac output to be the most important factor (Richardson et al., 1960; Rokseth et al., 1962). Dollery, EmslieSmith, and Shillingford (1961) thought the postural hypotensive effect was to some extent due to a failure of vasoconstriction to compensate for the normal reduction in cardiac output on standing.

There is a similar lack of agreement about the action of methyldopa. Sannerstedt, Varnauskas, and Werkö (1962) reported a dominant action on peripheral resistance, whereas Wilson, Fisher, and Kirkendall (1962) noted a fall in cardiac output with no significant change in peripheral resistance. Onesti et al. (1962) and Dollery, Harington, and Hodge (1963) found a reduction in both peripheral resistance and cardiac output in most of the patients they studied.

There are several reasons for the apparent disparity in the results obtained by different workers. First, in some series, observations were made with subjects supine, and are of limited value in investigating the action of drugs that produce their greatest effect with patients in the upright position. Secondly, most hæmodynamic studies were of the acute effects of the drugs given intravenously: their pharmacology is complicated, and the results may not be comparable to those obtained in investigations of the long-term action of orally administered drugs. Thirdly, the response of patients in heart failure to hypotensive agents is peculiar in that a fall in atrial filling pressure resulting from venous pooling may increase cardiac output (Freis et al., 1953): data obtained from a study of patients with raised venous pressure are therefore not applicable to those in whom it is normal. Finally, there is almost certainly more than one mechanism by which guanethidine and methyldopa reduce blood pressure, and the pattern of response may vary from patient to patient.

In this paper, we report the effects on blood pressure, heart rate, and cardiac output of routine treatment of hypertensive patients with oral guanethidine and methyldopa. We have made our observations with the patients supine, propped upright, and walking, both before treatment and after stabilization. We have, therefore, collected our data under conditions that are as relevant as possible to the normal management of hypertension.

\section{Patients ANd Methods}

Fifteen patients with a diagnosis of essential hypertension $(9$ men and 6 women, whose ages ranged from 36 to 71 years) agreed to take part in this study. None had any history of frank heart failure, although several complained of exertional dyspnœa. Four patients (Nos. 2, 5, 6, and 9) had papillœdema before treatment. The electrocardiograms of 13 patients indicated left ventricular hypertrophy and strain, and one of 
these showed previous myocardial infarction. There was radiological evidence of cardiomegaly in 9 patients, with a cardiothoracic ratio of $1: 2$ or more.

Observations were made before treatment was started, and they were repeated after stabilization on oral guanethidine or methyldopa, when the clinician in charge of the patient was satisfied with the fall in blood pressure. Six patients were treated with guanethidine and 10 with methyldopa, the dose of guanethidine ranging from 30 to $90 \mathrm{mg}$., and of methyldopa from 750 to $3000 \mathrm{mg}$. per day. One patient received the two drugs in turn, and is included in both series. Three of the patients treated with guanethidine and two of those treated with methyldopa were already taking a thiazide diuretic before the control measurements were made. In these cases, the dose of the thiazide was left unchanged throughout.

All the patients were shown the cardiac laboratory, and the techniques used were fully explained to them on a day before the control observations were made.

Cardiac output, blood pressure, and heart rate were measured with patients supine, standing upright but propped to achieve more stable conditions, and in most cases during exercise on a motor-driven treadmill at the end of the third minute of walking. The effort tolerance of the patients varied considerably: the speed and slope of the treadmill were adjusted to provide a moderate degree of exertion, and were kept constant for each individual patient. The speed ranged from 1.7 m.p.h. without slope to $2.4 \mathrm{~m} . \mathrm{p} . \mathrm{h}$. at an incline of $7^{\circ}$. The supine measurements were made in duplicate, and in most instances the standing measurements were also made twice. Two standing outputs were disregarded because the patients became syncopal while they were being recorded. The average difference in the paired supine outputs was 6.8 per cent; of the 17 standing outputs that were satisfactorily duplicated, the average difference was 8.9 per cent. In each case, the mean of the two figures was accepted.

Cardiac output was estimated by a dye dilution technique with the Cambridge earpiece and mark 2 recorder. Nylon catheters were introduced percutaneously over a Seldinger guide wire into antecubital veins, one in each arm, and passed about $18 \mathrm{in}$. $(46 \mathrm{~cm}$.) to bring them near the origin of the superior vena cava. One catheter was used for injections of 2 per cent Coomassie Blue, and the other, with multiple side holes near the tip, for obtaining samples of venous blood. Blank and tail samples were usually taken for each curve, because, when using an earpiece, calibration does not remain constant with changes in posture or on exercise. Arterial sampling has been found to be unnecessary provided adequate time is allowed for complete mixing; this was confirmed during each experiment by taking two venous tail samples separated by approximately 30 seconds during at least one of the output determinations. There were a few instances in which only one standing curve was calibrated because of technical difficulties in sampling, and the second standing cardiac output was then calculated from the first by comparing the ratios of the areas under the curves. Adequate baselines were obtained for the exercise curves by fitting a pad of polyester foam around the earpiece, and securing this with a crêpe bandage. Satisfactory observations during treadmill walking were made in 5 of the patients treated with guanethidine and in 7 treated with methyldopa. Examples of exercise curves obtained from 3 of these patients are shown in Fig. 1.

Heart rates were obtained by means of a direct writing electrocardiograph, with two electrodes held in place by a single strap around the chest. Blood pressures were measured using a sphygmomanometer cuff and a stethoscope diaphragm strapped over the left antecubital fossa. Stroke volume could be calculated because simultaneous cardiac output estimations and heart rates were obtained. Mean pressure was taken to be diastolic pressure plus one-third of the pulse pressure (Scheinberg and Stead, 1949), and peripheral resistance was calculated in arbitrary units by dividing this figure by cardiac output expressed in litres per minute.

\section{RESULTS}

The effect of the drugs on the blood pressure, with the patients supine, standing, and walking, is set out in Table I, and illustrated in Fig. 2A and B. The average falls in supine pressures were $11 \mathrm{~mm}$. systolic and $15 \mathrm{~mm}$. diastolic for guanethidine, and $22 \mathrm{~mm}$. systolic and $17 \mathrm{~mm}$. diastolic for methyldopa. The effect on standing pressures was much more: guanethidine produced an average fall in systolic pressure of $40 \mathrm{~mm}$. and in diastolic pressure of $34 \mathrm{~mm}$., whereas the corresponding figures for methyldopa were $42 \mathrm{~mm}$. and $27 \mathrm{~mm}$. The pressures were also lower on walking after the drugs in the 12 patients on whom observations were made, guanethidine causing an average fall of $52 \mathrm{~mm}$. in systolic and $43 \mathrm{~mm}$. in diastolic pressures, and methyldopa causing falls of $50 \mathrm{~mm}$. and $27 \mathrm{~mm}$. respectively. The over-all effect on pressure of the two drugs in the doses used was therefore comparable. 

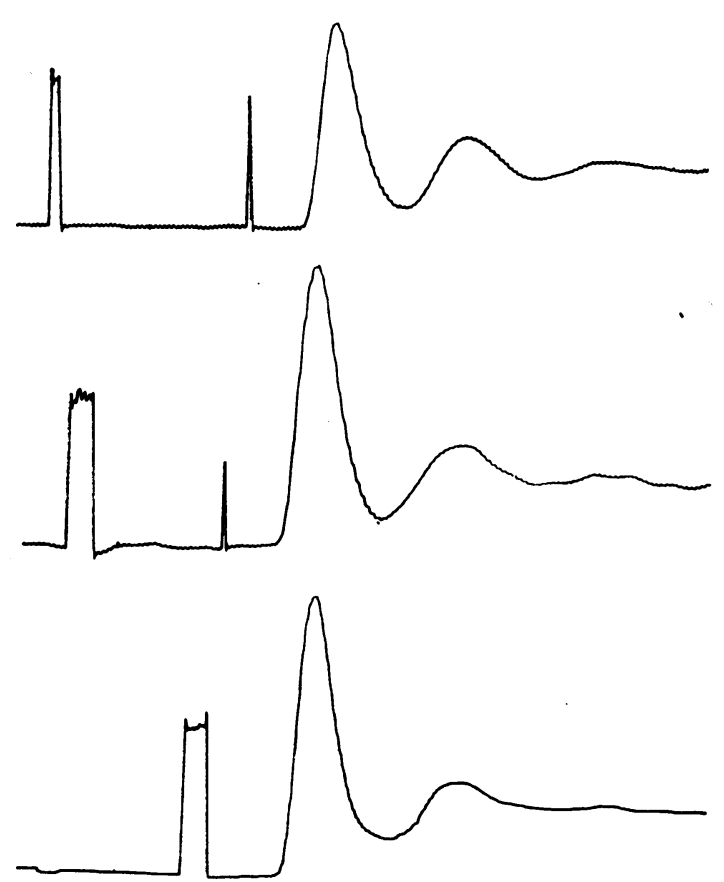

FIG. 1.-Earpiece dye curves obtained during treadmill exercise in three patients.

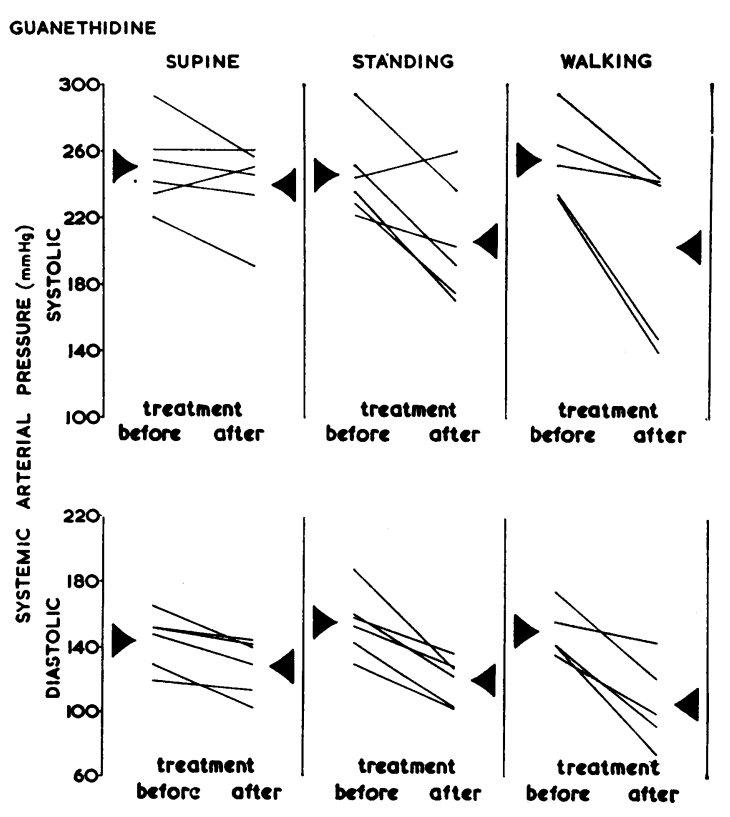

A
Heart rate was slowed by both drugs (Table II): with each, the percentage fall in rate was very similar for lying, standing, and for walking. However, the average slowing produced by guanethidine $(28 \%)$ was nearly three times as great as the average slowing produced by methyldopa $(11 \%)$.

Cardiac output was affected in a more variable manner (Table III, cardiac index). It was increased in the supine position in 6 patients and in the standing position in 5 patients treated with methyldopa; of the 6 on guanethidine, 2 had an increased supine output, and 3 an increased standing output. We were able to compare cardiac output during treadmill walking before and after treatment in a total of 12 patients, and in only 2 did we find a fall. On average, the exercise output was increased by more than 20 per cent.

In most patients in whom the cardiac output fell, the fall was proportionately less than the reduction in heart rate. Treatment therefore resulted in an increase in stroke volume in 13 of the 16 cases at rest, and in 11 out of 12 on exercise (Table IV). The increase was greater with

METHYL DOPA
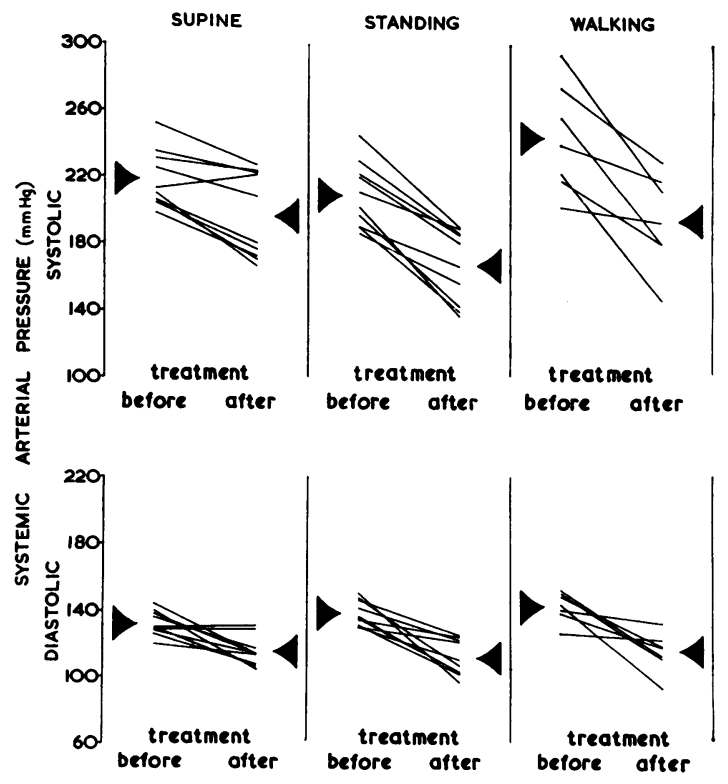

B

FIG. 2.-(A) The effect of guanethidine on blood pressure in patients supine, standing, and during walking exercise. (B) The effect of methyldopa on blood pressure in patients supine, standing, and during walking exercise. The arrows indicate mean values. 
TABLE I

Blood Pressures Before and After Treatment (mm. Hg)

\begin{tabular}{|c|c|c|c|c|c|c|}
\hline \multirow[b]{2}{*}{ Patient } & \multicolumn{2}{|c|}{ Supine } & \multicolumn{2}{|c|}{ Standing } & \multicolumn{2}{|c|}{ Exercise } \\
\hline & $\begin{array}{c}\text { Before } \\
\text { treatment }\end{array}$ & $\begin{array}{c}\text { After } \\
\text { treatment }\end{array}$ & $\begin{array}{c}\text { Before } \\
\text { treatment }\end{array}$ & $\begin{array}{c}\text { After } \\
\text { treatment }\end{array}$ & $\begin{array}{c}\text { Before } \\
\text { treatment }\end{array}$ & $\begin{array}{c}\text { After } \\
\text { treatment }\end{array}$ \\
\hline $\begin{array}{c}\text { Guanethidine } \\
1 \\
2 \\
3 \\
4 \\
5 \\
6\end{array}$ & $\begin{array}{l}242 / 148 \\
261 / 153 \\
235 / 120 \\
293 / 165 \\
255 / 153 \\
220 / 130\end{array}$ & $\begin{array}{l}232 / 130 \\
261 / 145 \\
251 / 114 \\
257 / 140 \\
247 / 142 \\
191 / 103\end{array}$ & $\begin{array}{l}245 / 159 \\
253 / 154 \\
223 / 132 \\
294188 \\
236 / 161 \\
229 / 144\end{array}$ & $\begin{array}{l}260 / 138 \\
192 / 130 \\
203 / 104 \\
237 / 129 \\
171 / 124 \\
175 / 105\end{array}$ & $\begin{array}{l}264 / 176 \\
252 / 158 \\
294 / 138 \\
232 / 144 \\
234 / 144\end{array}$ & $\begin{array}{c}240 / 124 \\
242 / 146 \\
244 / 102 \\
- \\
140 / 95 \\
148 / 78\end{array}$ \\
\hline $\begin{array}{r}\text { Mernyiapa } \\
7 \\
8 \\
9 \\
10 \\
11 \\
12 \\
13 \\
14 \\
15 \\
16\end{array}$ & $\begin{array}{l}232 / 135 \\
210 / 127 \\
206 / 144 \\
225 / 140 \\
205 / 127 \\
198 / 130 \\
252 / 138 \\
213 / 131 \\
205 / 129 \\
235 / 120\end{array}$ & $\begin{array}{l}224 / 117 \\
166 / 107 \\
170 / 115 \\
208 / 104 \\
176 / 114 \\
172 / 106 \\
227 / 114 \\
221 / 131 \\
180 / 129 \\
222 / 113\end{array}$ & $\begin{array}{l}211 / 146 \\
197 / 136 \\
205 / 148 \\
245 / 147 \\
190 / 135 \\
190 / 130 \\
230 / 130 \\
220 / 141 \\
186 / 134 \\
223 / 132\end{array}$ & $\begin{array}{l}189 / 126 \\
142 / 102 \\
136 / 96 \\
190 / 106 \\
139 / 102 \\
166 / 121 \\
186 / 110 \\
180 / 122 \\
156 / 125 \\
185 / 101\end{array}$ & $\begin{array}{c}\overline{-} \\
222 / 143 \\
274 / 152 \\
202 / 148 \\
240 / 140 \\
256 / 150 \\
218 / 126 \\
294 / 135\end{array}$ & $\begin{array}{c}\overline{-} \\
146 / 92 \\
230 / 112 \\
193 / 118 \\
218 / 132 \\
\overline{180 / 110} \\
180 / 122 \\
212 / 117\end{array}$ \\
\hline
\end{tabular}

guanethidine, because this drug had more action on the heart rate. The average percentage increases in stroke volume with the patients supine, standing, and walking were 42,49 , and 48 per cent respectively on guanethidine, and the corresponding figures for methyldopa were 11,29 , and 39 per cent.

Peripheral resistance (Table V) in the supine and standing positions fell in 8 of the patients who received methyldopa and in 5 of the 6 patients treated with guanethidine. Of the 12 patients who were exercised, the peripheral resistance fell in 11. In most instances, the fall was greater on exercise than it was at rest.

TABLE II

Heart Rates Before and After Treatment

\begin{tabular}{|c|c|c|c|c|c|c|c|c|c|}
\hline \multirow[b]{2}{*}{ Patient } & \multicolumn{3}{|c|}{ Supine } & \multicolumn{3}{|c|}{ Standing } & \multicolumn{3}{|c|}{ Exercise } \\
\hline & $\begin{array}{c}\text { Before } \\
\text { treatment }\end{array}$ & $\begin{array}{c}\text { After } \\
\text { treatment }\end{array}$ & $\begin{array}{l}\text { Per cent } \\
\text { change }\end{array}$ & $\begin{array}{c}\text { Before } \\
\text { treatment }\end{array}$ & $\begin{array}{c}\text { After } \\
\text { treatment }\end{array}$ & $\begin{array}{l}\text { Per cent } \\
\text { change }\end{array}$ & $\begin{array}{c}\text { Before } \\
\text { treatment }\end{array}$ & $\begin{array}{c}\text { After } \\
\text { treatment }\end{array}$ & $\begin{array}{l}\text { Per cent } \\
\text { change }\end{array}$ \\
\hline $\begin{array}{c}\text { Guanethi } \\
1 \\
2 \\
3 \\
4 \\
5 \\
6 \\
\text { Methyldo }\end{array}$ & ine $\begin{array}{r}77 \\
97 \\
88 \\
90 \\
83 \\
64\end{array}$ & $\begin{array}{l}54 \\
56 \\
71 \\
66 \\
60 \\
45\end{array}$ & $\begin{array}{l}-30 \\
-42 \\
-19 \\
-27 \\
-28 \\
-30\end{array}$ & $\begin{array}{r}90 \\
100 \\
100 \\
96 \\
95 \\
75\end{array}$ & $\begin{array}{l}59 \\
63 \\
77 \\
66 \\
76 \\
54\end{array}$ & $\begin{array}{l}-34 \\
-35 \\
-23 \\
-31 \\
-20 \\
-28\end{array}$ & $\begin{array}{l}105 \\
136 \\
122 \\
109 \\
111\end{array}$ & $\begin{array}{r}73 \\
89 \\
103 \\
88 \\
83\end{array}$ & $\begin{array}{l}-30 \\
-35 \\
-16 \\
-19 \\
-19 \\
-25\end{array}$ \\
\hline $\begin{array}{r}7 \\
8 \\
9 \\
10 \\
11 \\
12 \\
13 \\
14 \\
15 \\
16\end{array}$ & $\begin{array}{l}66 \\
83 \\
84 \\
83 \\
64 \\
66 \\
75 \\
67 \\
73 \\
88\end{array}$ & $\begin{array}{l}60 \\
89 \\
71 \\
64 \\
54 \\
57 \\
47 \\
66 \\
96 \\
70\end{array}$ & $\begin{array}{l}-9 \\
+7 \\
-16 \\
-23 \\
-16 \\
-14 \\
-37 \\
-1 \\
+31 \\
-20\end{array}$ & $\begin{array}{r}73 \\
107 \\
105 \\
86 \\
75 \\
74 \\
85 \\
72 \\
102 \\
100\end{array}$ & $\begin{array}{r}66 \\
90 \\
92 \\
64 \\
55 \\
56 \\
58 \\
71 \\
118 \\
79\end{array}$ & $\begin{array}{l}-10 \\
-16 \\
-12 \\
-26 \\
-27 \\
-14 \\
-32 \\
-1 \\
+16 \\
-21\end{array}$ & $\begin{array}{r}- \\
122 \\
107 \\
96 \\
136 \\
\overline{82} \\
136 \\
122\end{array}$ & $\begin{array}{r}- \\
105 \\
86 \\
90 \\
130 \\
\overline{81} \\
134 \\
103\end{array}$ & $\begin{array}{l}- \\
-14 \\
-20 \\
-6 \\
-4 \\
-1 \\
-1 \\
-16\end{array}$ \\
\hline
\end{tabular}


TABLE III

Cardiac Index Before and After Treatment (1./min./m. $\left.{ }^{2}\right)$

\begin{tabular}{|c|c|c|c|c|c|c|c|c|c|}
\hline \multirow[b]{2}{*}{ Patient } & \multicolumn{3}{|c|}{ Supine } & \multicolumn{3}{|c|}{ Standing } & \multicolumn{3}{|c|}{ Exercise } \\
\hline & $\begin{array}{c}\text { Before } \\
\text { treatment }\end{array}$ & $\begin{array}{c}\text { After } \\
\text { treatment }\end{array}$ & $\begin{array}{l}\text { Per cent } \\
\text { change }\end{array}$ & $\begin{array}{c}\text { Before } \\
\text { treatment }\end{array}$ & $\begin{array}{c}\text { After } \\
\text { treatment }\end{array}$ & $\begin{array}{l}\text { Per cent } \\
\text { change }\end{array}$ & $\begin{array}{c}\text { Before } \\
\text { treatment }\end{array}$ & $\begin{array}{c}\text { After } \\
\text { treatment }\end{array}$ & $\begin{array}{c}\text { Per cent } \\
\text { change }\end{array}$ \\
\hline $\begin{array}{c}\text { Guanethi } \\
1 \\
2 \\
3 \\
4 \\
5 \\
6 \\
\text { Methyldo }\end{array}$ & ine $\begin{array}{r} \\
3 \cdot 3 \\
4 \cdot 3 \\
3 \cdot 0 \\
4 \cdot 6 \\
2 \cdot 5 \\
2 \cdot 8\end{array}$ & $\begin{array}{l}3 \cdot 1 \\
3 \cdot 8 \\
3 \cdot 9 \\
4 \cdot 4 \\
2 \cdot 7 \\
2 \cdot 4\end{array}$ & $\begin{array}{l}-6 \\
-12 \\
+30 \\
-4 \\
+8 \\
-14\end{array}$ & $\begin{array}{l}2 \cdot 7 \\
3 \cdot 4 \\
2 \cdot 3 \\
3 \cdot 6 \\
2 \cdot 2 \\
3 \cdot 1\end{array}$ & $\begin{array}{l}3 \cdot 2 \\
2 \cdot 7 \\
3 \cdot 0 \\
4 \cdot 1 \\
2 \cdot 1 \\
2 \cdot 7\end{array}$ & $\begin{array}{l}+19 \\
-21 \\
+30 \\
+14 \\
-5 \\
-13\end{array}$ & $\begin{array}{l}4 \cdot 5 \\
8 \cdot 3 \\
5 \cdot 2 \\
4 \cdot 0 \\
6 \cdot 0\end{array}$ & $\begin{array}{l}5 \cdot 9 \\
5 \cdot 3 \\
7 \cdot 5 \\
-4 \cdot 0 \\
7 \cdot 4\end{array}$ & $\begin{array}{c}+31 \\
-36 \\
+44 \\
-0 \\
+23\end{array}$ \\
\hline $\begin{array}{r}7 \\
8 \\
9 \\
10 \\
11 \\
12 \\
13 \\
14 \\
15 \\
16\end{array}$ & $\begin{array}{l}3 \cdot 1 \\
3 \cdot 8 \\
3 \cdot 9 \\
3 \cdot 4 \\
2 \cdot 1 \\
3 \cdot 1 \\
3 \cdot 5 \\
2 \cdot 7 \\
3 \cdot 3 \\
3 \cdot 0\end{array}$ & $\begin{array}{l}3 \cdot 5 \\
4 \cdot 4 \\
3 \cdot 3 \\
3 \cdot 5 \\
1 \cdot 9 \\
3 \cdot 3 \\
1 \cdot 8 \\
3 \cdot 1 \\
3 \cdot 2 \\
3 \cdot 1\end{array}$ & $\begin{array}{l}+13 \\
+16 \\
-15 \\
+3 \\
-10 \\
+6 \\
-49 \\
+15 \\
-3 \\
+3\end{array}$ & $\begin{array}{l}1 \cdot 8 \\
3 \cdot 0 \\
4 \cdot 4 \\
2 \cdot 8 \\
1 \cdot 6 \\
2 \cdot 3 \\
2 \cdot 9 \\
2 \cdot 1 \\
1 \cdot 8 \\
2 \cdot 3\end{array}$ & $\begin{array}{l}2 \cdot 5 \\
3 \cdot 7 \\
3 \cdot 2 \\
2 \cdot 8 \\
1 \cdot 6 \\
3 \cdot 8 \\
2 \cdot 1 \\
2 \cdot 3 \\
1 \cdot 6 \\
2 \cdot 4\end{array}$ & $\begin{array}{c}+39 \\
+23 \\
-27 \\
0 \\
0 \\
+65 \\
-28 \\
+10 \\
-11 \\
+4\end{array}$ & $\begin{array}{l}- \\
4 \cdot 8 \\
5 \cdot 5 \\
4 \cdot 3 \\
8 \cdot 2 \\
\overline{4} \\
8 \cdot 3 \\
5 \cdot 2\end{array}$ & $\begin{array}{c}- \\
\overline{7} \cdot 1 \\
5 \cdot 1 \\
4 \cdot 4 \\
11 \cdot 4 \\
\overline{5 \cdot 6} \\
11 \cdot 1 \\
7 \cdot 3\end{array}$ & $\begin{array}{l}- \\
-48 \\
+7 \\
+2 \\
+39 \\
-30 \\
+34 \\
+30\end{array}$ \\
\hline
\end{tabular}

\section{DisCUSSION}

Guanethidine is a powerful inhibitor of the sympathetic system, and acts both by depleting tissues of catecholamines, a reserpine-like action, and also by a peripheral blocking action on sympathetic post-ganglionic nerve endings similar to that of bretylium (Burn, 1961). Methyldopa was originally believed to owe its effect to noradrenaline depletion by inhibition of decarboxylase, an enzyme essential to its synthesis (Sourkes, 1954; Oates et al., 1960). However, there is now evidence that the

TABLE IV

Stroke Volume Before ANd After Treatment (ml./beat)

\begin{tabular}{|c|c|c|c|c|c|c|c|c|c|}
\hline \multirow[b]{2}{*}{ Patient } & \multicolumn{3}{|c|}{ Supine } & \multicolumn{3}{|c|}{ Standing } & \multicolumn{3}{|c|}{ Exercise } \\
\hline & $\begin{array}{c}\text { Before } \\
\text { treatment }\end{array}$ & $\begin{array}{c}\text { After } \\
\text { treatment }\end{array}$ & $\begin{array}{l}\text { Per cent } \\
\text { change }\end{array}$ & $\begin{array}{c}\text { Before } \\
\text { treatment }\end{array}$ & $\begin{array}{c}\text { After } \\
\text { treatment }\end{array}$ & $\begin{array}{l}\text { Per cent } \\
\text { change }\end{array}$ & $\begin{array}{c}\text { Before } \\
\text { treatment }\end{array}$ & $\begin{array}{c}\text { After } \\
\text { treatment }\end{array}$ & $\begin{array}{l}\text { Per cent } \\
\text { change }\end{array}$ \\
\hline $\begin{array}{c}\text { Guanethi } \\
1 \\
2 \\
3 \\
4 \\
5 \\
6 \\
\text { Methyldo }\end{array}$ & ne $\begin{array}{r} \\
66 \\
72 \\
58 \\
100 \\
54 \\
83\end{array}$ & $\begin{array}{r}86 \\
110 \\
93 \\
130 \\
87 \\
96\end{array}$ & $\begin{array}{l}+30 \\
+53 \\
+60 \\
+30 \\
+61 \\
+16\end{array}$ & $\begin{array}{l}45 \\
55 \\
38 \\
73 \\
43 \\
75\end{array}$ & $\begin{array}{r}81 \\
68 \\
67 \\
122 \\
54 \\
91\end{array}$ & $\begin{array}{l}+80 \\
+24 \\
+76 \\
+67 \\
+26 \\
+21\end{array}$ & $\begin{array}{r}65 \\
100 \\
73 \\
69 \\
99\end{array}$ & $\begin{array}{r}122 \\
98 \\
123 \\
85 \\
163\end{array}$ & $\begin{array}{l}+88 \\
-2 \\
+68 \\
-23 \\
+23 \\
+65\end{array}$ \\
\hline $\begin{array}{r}7 \\
8 \\
9 \\
10 \\
11 \\
12 \\
13 \\
14 \\
15 \\
16\end{array}$ & $\begin{array}{r}92 \\
87 \\
89 \\
69 \\
46 \\
104 \\
88 \\
62 \\
87 \\
58\end{array}$ & $\begin{array}{r}118 \\
94 \\
87 \\
92 \\
50 \\
132 \\
71 \\
73 \\
63 \\
74\end{array}$ & $\begin{array}{l}+28 \\
+8 \\
-2 \\
+33 \\
+9 \\
+27 \\
-19 \\
+18 \\
-28 \\
+28\end{array}$ & $\begin{array}{l}50 \\
53 \\
79 \\
54 \\
29 \\
72 \\
64 \\
44 \\
35 \\
38\end{array}$ & $\begin{array}{r}75 \\
78 \\
66 \\
73 \\
42 \\
152 \\
67 \\
49 \\
26 \\
52\end{array}$ & $\begin{array}{l}+50 \\
+47 \\
-16 \\
+35 \\
+45 \\
+111 \\
-5 \\
+11 \\
-26 \\
+37\end{array}$ & $\begin{array}{r}- \\
\overline{75} \\
85 \\
64 \\
135 \\
\overline{79} \\
118 \\
73\end{array}$ & $\begin{array}{r}- \\
\overline{128} \\
99 \\
69 \\
198 \\
\overline{105} \\
160 \\
120\end{array}$ & $\begin{array}{l}- \\
\overline{+71} \\
+16 \\
+8 \\
+47 \\
- \\
+33 \\
+36 \\
+64\end{array}$ \\
\hline
\end{tabular}


TABLE V

Peripheral Resistance Before and After Treatment

(in arbitrary units obtained by dividing approximate systemic gradient in $\mathrm{mm}$. $\mathrm{Hg}$ by cardiac output in $1 . / \mathrm{min}$.)

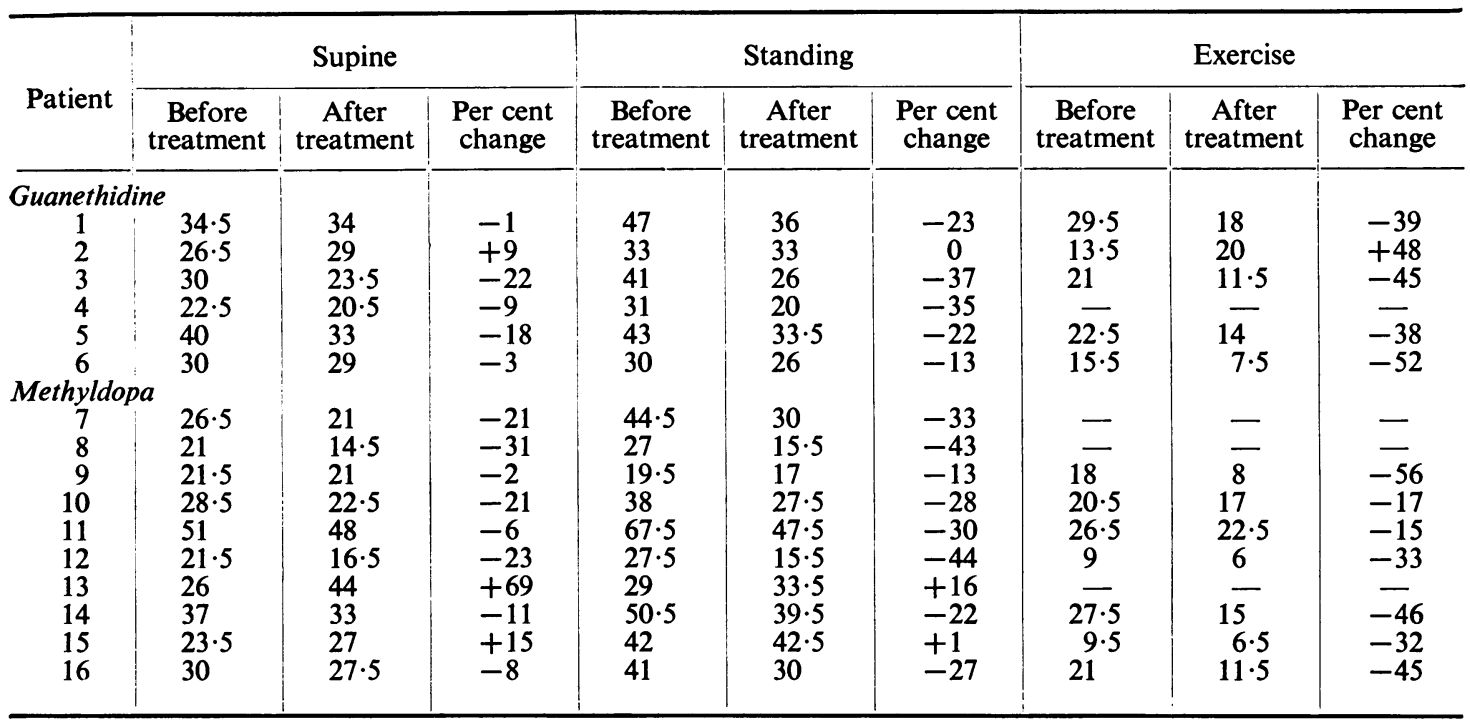

drug is itself decarboxylated in vivo, and follows the same metabolic pathways as noradrenaline to form $\alpha$-methylnoradrenaline (Carlsson and Lindqvist, 1962). This accounts for the observation that treatment with methyldopa does not reduce the excretion of metabolites of noradrenaline (Cannon et al., 1962). $\quad \alpha$-methylnoradrenaline can be utilized as a transmitter at sympathetic nerve endings (Day and Rand, 1963), but its activity is weaker than that of noradrenaline.

The regulation of circulatory dynamics is complex, and there are three principal ways in which sympathetic blockade might diminish cardiac output or peripheral resistance and therefore lower blood pressure: first, by decreasing myocardial contractility and heart rate; secondly, by reducing arteriolar tone; and thirdly, by an effect on venous tone, causing venous pooling in the upright position, and therefore limiting venous return. Further, a fall in blood pressure normally stimulates carotid sinus reflexes, and in addition to increasing peripheral resistance, these can augment cardiac output by causing venoconstriction, by increasing myocardial contractility, and by increasing heart rate (Sarnoff and Mitchell, 1961); these compensatory mechanisms will also be depressed by sympathetic blockade.

It is possible to inhibit sympathetic drive on the heart with little effect on vascular tone by using the recently introduced $\beta$-sympathetic blocking drugs. In a study of the effects of pronethalol on healthy volunteers (Chamberlain and Howard, 1964) we have shown that the resulting slowing of the heart rate and diminished contractility is not usually accompanied by any significant fall in cardiac output at rest or, more surprisingly, on exercise. The reduction in heart rate is compensated by an increased stroke volume, indicating that, with an efficient myocardium, the sympathetic tone of the heart does not have an important effect in determining cardiac output. Whereas nearly all the patients treated with guanethidine and methyldopa do have slowing of the heart rate, many do not have an efficient myocardium. It is of interest that of the 8 patients in whom the supine outputs were reduced by treatment, 7 had radiological evidence of cardiac enlargement, with a cardiothoracic ratio of $1: 2$ or more. Only two patients had some cardiac enlargement without a fall in supine output. It seems that guanethidine and methyldopa are likely to cause a reduction in supine cardiac output particularly in patients with cardiomegaly in whom the stroke volume cannot increase to compensate for the bradycardia which has been induced. 


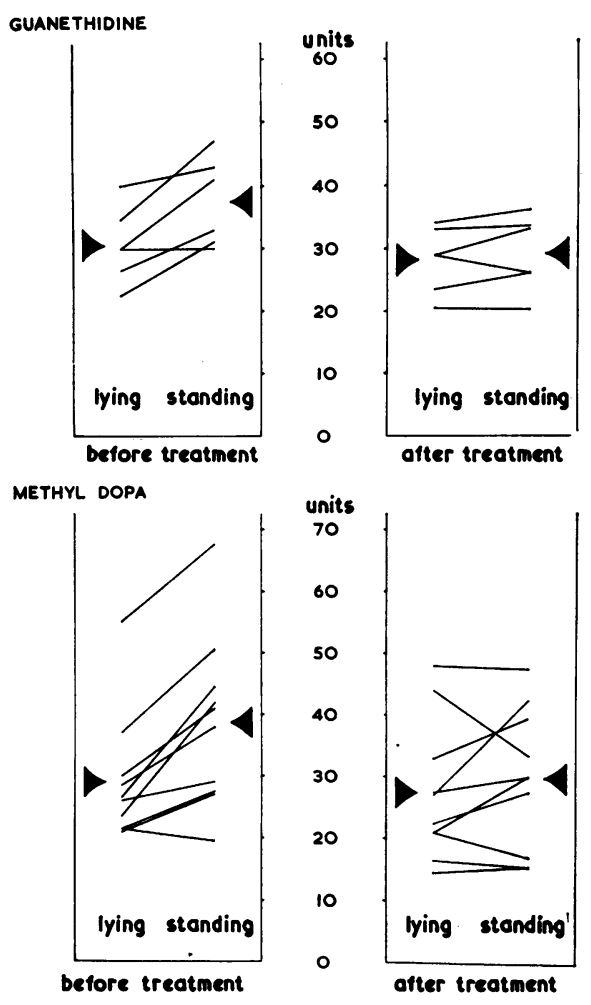

Fig. 3.-Change in peripheral resistance from lying to standing before and after treatment with guanethidine and methyldopa. The arrows indicate mean values.
In the present series, guanethidine caused greater slowing of the heart rate than did methyldopa, both at rest and on exercise, although the effect on blood pressure of the two drugs was comparable. The bradycardia induced by guanethidine is due to the removal of sympathetic tone. If the substitution of $\alpha$-methylnoradrenaline at sympathetic nerve endings be accepted as the mode of action of methyldopa, it is reasonable to assume that this false transmitter has a relatively greater action on heart rate than it does on vascular tone.

Peripheral resistance in the supine position was lower on treatment in all but three patients, and these were in the group who showed a reduction in cardiac output. There was little difference in this respect between the two drugs. There is therefore evidence of an effect on arteriolar tone which was chiefly responsible for the small falls in pressure obtained in the supine position.

With one exception, the patients had a further fall in pressure on standing: this postural effect resulted from a reduction in cardiac output, presumably due to venous pooling. The increased fall in systolic pressure in the upright position averaged 14 per cent on guanethidine and 15 per cent on methyldopa; these pressure changes were accompanied by falls in cardiac output of 12 and 16 per cent respectively. At first sight, this might appear to lend support to the contention that the drugs act principally by inducing venous pooling (Richardson et al., 1960; Rokseth et al., 1962). This is a false deduction. A fall in cardiac output from lying to standing is a normal hæmodynamic response, compensated by increased peripheral resistance. In the present series, the average fall in output from lying to standing before treatment was 19 per cent, whereas the corresponding figure after treatment was 15 per cent. However, the normal compensatory increase in peripheral resistance on standing was reduced or abolished by the drugs, resulting in a fall in blood pressure: this effect is illustrated in Fig. 3. As far as we know, only Dollery et al. (1961) in a study of patients treated with guanethidine have previously stressed this as a likely principal mechanism of action. On the evidence of the small number of patients studied, we cannot exclude increased venous pooling as one factor that may play a part in the postural hypotension induced by the drugs, but it is clear that it is unimportant in most patients.

This apparently conflicts with several other reports on the hæmodynamic effects of the drugs. Richardson et al. (1960) concluded from their study of patients on oral guanethidine that the drug lowered the blood pressure by a reduction in cardiac output, due to peripheral pooling or possibly altered myocardial contractility. They found a 10 per cent reduction in supine output and a 33 per cent reduction in standing output on the drug, but these changes were with reference to the supine values before treatment. Their data show that there was in fact a 17 per cent reduction in cardiac output from lying to standing before treatment, and a 25 per cent reduction from lying to standing afterwards. The behaviour of peripheral resistance in their patients was very similar to what we have observed: it was a little lower in the supine position after treatment, and failed to rise on tilting to compensate for the normal fall in cardiac output. Rokseth et al. (1962) studied 22 patients before 
and after guanethidine, all except one of whom had pulmonary but not systemic hypertension; the drug was administered intravenously and the observations were made in the supine position. Wilson et al. (1962) measured the cardiac output in five patients before and after intravenous methyldopa, and again the observations were made in the supine position. These results are, therefore, not necessarily relevant to the everyday treatment of hypertension.

Hypotension during exercise experienced by some patients on sympathetic blocking drugs has aroused interest since it was first reported with guanethidine by Leishman, Matthews, and Smith (1959). Lowe and Rosenheim (1960) suggested this might be caused by a failure of the cardiac output to rise normally on exercise. Later, Dollery et al. (1961) and Taylor et al. (1962) showed that cardiac output did rise in a normal fashion on exercise, but these observations were made with the subjects in the supine position. Sannerstedt et al. (1962) also found little effect on the cardiac output during exercise on a bicycle ergometer after treatment with oral methyldopa. In the present study, cardiac output was measured during treadmill walking: observations were made, therefore, under conditions as close as possible to normal, and the amount of exercise could be accurately standardized for each patient. There were no cases of severe exercise hypotension, but the falls in pressure were usually greater than those observed with the patients supine or standing: they averaged $52 \mathrm{~mm}$. systolic and $43 \mathrm{~mm}$. diastolic with guanethidine, and $50 \mathrm{~mm}$. systolic and $27 \mathrm{~mm}$. diastolic with methyldopa compared with control readings. The percentage reductions in heart rate were similar to those found at rest, averaging 25 per cent for guanethidine and 9 per cent for methyldopa. Despite the reduction in exercise tachycardia and the diminished myocardial contractility likely to result from sympathetic blockade, the cardiac output of exercise was usually greater after treatment, and fell in only 2 patients: Patient 2 had cardiac enlargement and diminished output both at rest and on exercise after guanethidine, and Patient 10, who was treated with methyldopa, had a very small reduction during exercise, but not at rest. As a result of these effects on heart rate and cardiac output, stroke volume was increased in all but one patient, the increase averaging 48 per cent for guanethidine and 39 per cent for methyldopa. The large falls in blood pressure during exercise were therefore achieved by a greater than usual decrease in peripheral resistance, despite a usually augmented exercise output. We had no opportunity to study patients with severe exertional hypotension, and so our observations do not settle with certainty the question of whether this particular phenomenon is due to an effect on peripheral resistance or a failure in certain patients to achieve a normal increase in exercise output.

\section{SUMMARY}

The blood pressure, heart rate, and cardiac output were measured in 6 patients before and after treatment with oral guanethidine, and in 10 patients before and after treatment with oral methyldopa. Observations were made with the patients supine, standing, and during treadmill walking. Patients were therefore studied under conditions as relevant as possible to the ordinary treatment of hypertension. Both drugs produced their hypotensive response principally by lowering peripheral resistance: their effect was greater when patients were upright because the increase in peripheral resistance that compensates for the normal fall in cardiac output in this position was reduced or abolished. Heart rate was reduced by both drugs, and in this respect guanethidine was more potent than methyldopa. The slowing of the heart rate was usually compensated by an increased stroke volume, and in many cases cardiac output was greater on treatment especially during exercise. Of the 8 patients in whom the supine output fell, 7 had radiological evidence of cardiac enlargement; it is postulated that in these patients the stroke volume may be unable to increase sufficiently to compensate for the slower heart rate. The biggest falls in blood pressure were obtained on exercise, and this was due to a greater than normal decrease in peripheral resistance: it occurred despite the fact that cardiac output was raised to more than pre-treatment levels in most cases. There was little difference in the hæmodynamic effects of the two drugs, except that guanethidine caused more slowing of the heart rate and therefore greater increases in stroke volume. 
This work was done while D.A.C. was in receipt of an Aylwen Research Bursary.

We wish to thank Dr. G. W. Hayward, Dr. D. Weitzman, and Dr. M. Honey for much help and advice, the Physicians of St. Bartholomew's Hospital for permission to study patients under their care, and the patients themselves for agreeing to take part. We are also grateful to Miss N. Roos and Miss M. Confavreux for some of the dye extractions.

\section{REFERENCES}

Burn, J. H. (1961). A new view of adrenergic nerve fibres, explaining the action of reserpine, bretylium, and guanethidine. Brit. med. J., 1, 1623.

Cannon, P. J., Whitlock, R. T., Morris, R. C., Angers, M., and Laragh, J. H. (1962). Effect of alpha-methyl dopa in severe and malignant hypertension. J. Amer. med. Ass., 179, 673.

Carlsson, A., and Lindqvist, M. (1962). In-vivo decarboxylation of $\alpha$-methyl dopa and $\alpha$-methyl metatyrosine. Acta physiol. scand., 54, 87.

Chamberlain, D. A., and Howard, J. (1964). The hæmodynamic effects of $\beta$-sympathetic blockade. Brit. Heart J., 26, 213.

Day, M. D., and Rand, M. J. (1963). A hypothesis for the mode of action of $\alpha$-methyldopa in relieving hypertension. J. Pharm. Pharmacol., 15, 221

Dollery, C. T., Emslie-Smith, D., and Shillingford, J. P. (1961). Hæmodynamic effects of guanethidine. Lancet, 2, 331.

- Harington, M., and Hodge, J. V. (1963). Hæmodynamic studies with methyldopa: effect on cardiac output and response to pressor amines. Brit. Heart J., 25, 670.

Freis, E. D., Rose, J. C., Partenope, E. A., Higgins, T. F., Kelley, R. T., Schnaper, H. W., and Johnson, R. L. (1953). The hæmodynamic effects of hypotensive drugs in man. III. Hexamethonium. J. clin. Invest., 32, 1285.

Leishman, A. W. D., Matthews, H. L., and Smith, A. J. (1959). Guanethidine: hypotensive drug with prolonged action. Lancet, 2, 1044.

Lichtlen, P., Schaub, F., and Bühlmann, A. (1960). Klinische und experimentelle Untersuchungen über die blutdrucksenkende Wirkung von Guanethidin. Dtsch. med. Wschr., 85, 1249.

Lowe, R. D., and Rosenheim, M. L. (1960). Bretylium tosylate in the treatment of hypertension. Lancet, 1, 655.

Oates, J. A., Gillespie, L., Udenfriend, S., and Sjoerdsma, A. (1960). Decarboxylase inhibition and blood pressure reduction by $\alpha$-methyl-3, 4-dihydroxy-DL-phenylalanine. Science, 131, 1890.

Onesti, G., Brest, A. N., Novack, P., and Moyer, J. H. (1962). Pharmacodynamic effects and clinical use of alpha methyldopa in the treatment of essential hypertension. Amer. J. Cardiol., 9, 863.

Richardson, D. W., Wyso, E. M., Magee, J. H., and Cavell, G. C. (1960). Circulatory effects of guanethidine. Circulation, 22, 184.

Rokseth, R., Storstein, O., Voll, A., Abrahamsen, A. M., and Ofstad, J. (1962). Circulatory and respiratory effects of guanethidin. Brit. Heart J., 24, 195.

Roy, S. B., Mathur, V.S., and Bhatia, M. L. (1961). Circulatory effects of guanethidine in hypertensive heart failure. Brit. med. J., 2, 1315.

Sannerstedt, R., Varnauskas, E., and Werkö, L. (1962). Hemodynamic effects of methyldopa (Aldomet) at rest and during exercise in patients with arterial hypertension. Acta med. scand., 171, 75.

Sarnoff, S. J., and Mitchell, J. H. (1961). The regulation of the performance of the heart. Amer. J. Med., 30, 747.

Scheinberg, P., and Stead, E. A. (1949). The cerebral blood flow in male subjects as measured by the nitrous oxide technique. Normal values for blood flow, oxygen utilization, glucose utilization, and peripherial resistance, with observations on the effect of tilting and anxiety. J. clin. Invest., 28, 1163.

Sourkes, T. L. (1954). Inhibition of dihydroxyphenylalanine decarboxylase by derivatives of phenylalanine. Arch. Biochem., 51, 444.

Taylor, S. H., Sutherland, G. R., Hutchison, D. C. S., Langford Kidd, B. S., Robertson, P. C., Kennelly, B. M., and Donald, K. W. (1962). The effects of intravenous guanethidine on the systemic and pulmonary circulations in man. Amer. Heart J., 63, 239.

Wilson, W. R., Fisher, F. D., and Kirkendall, W. M. (1962). The acute hemodynamic effects of $\alpha$-methyldopa in man. J. chron. Dis., 15, 907. 